\title{
Women and Politics
}




\section{Women and Politics}

Vicky Randall

Macmillan Education 


\section{(C) Vicky Randall 1982}

All rights reserved. For information, write:

St. Martin's Press, Inc., 175 Fifth Avenue, New York, NY 10010

First published in the United States of America in 1982

ISBN 978-0-333-30713-7 ISBN 978-1-349-16880-4 (eBook)

DOI 10.1007/978-1-349-16880-4

\section{Library of Congress Cataloging in Publication Data}

Randall, Vicky.

Women and politics.

Bibliography: p.

Includes index.

1. Women in politics - United States.

2. Feminism-United States. I. Title

HQ1236.R26 $1982 \quad 305.4^{\prime} 2^{\prime} 0973 \quad 82-10657$

ISBN 978-0-312-88729-2

ISBN 978-0-312-88728-5 (pbk.) 


\section{Contents}

Preface

Introduction

What is feminism?

What is politics?

1. Women's Place in Society

Male dominance or patriarchy?

The inevitability of male dominance?

2. Women's Political Behaviour

The extent of women's participation in grass-roots politics

Women's political attitudes

Determinants of women's political behaviour

3. Women in Political Elites

A minority presence

Why so few?

Strategies for women?

A distinctive contribution?

4. How Politics Affects Women

Politics and women's status in Britain

Explaining policy towards women: a comparative approach

5. The Politics of the Women's Movement

The 'first wave' of feminism

The origins of contemporary feminism

Women's liberation in the United States

Women's liberation in Britain

The movement elsewhere 
vi Contents

6. Feminism and Policy-Making 169

$\begin{array}{ll}\text { Abortion rights } & 169\end{array}$

$\begin{array}{ll}\text { Equal rights policy-making } & 180\end{array}$

$\begin{array}{ll}\text { Conclusion } & 199\end{array}$

Notes for Further Reading 206

$\begin{array}{ll}\text { Bibliography } & 208\end{array}$

$\begin{array}{ll}\text { Index } & 221\end{array}$ 
To my mother 


\section{Preface}

At one time convention tended to define women and politics as mutually exclusive, occupying different spheres. Politics was understood as a public activity dominated by men and requiring typically masculine characteristics. Women were identified above all with the private world of the family and domestic life.

Two generations of feminists dating from the mid-nineteenth century and the early 1960s have challenged this view. Both have contributed to important changes in attitudes and have, in their turn, moved issues such as women's suffrage, and abortion, rape and equal pay into the arena of public debate and conflict.

Feminism has shed new light on the relationship between women and politics both by pointing to the structural features of political life which have tended to exclude women from positions of power, and by recovering from oblivion a hidden history of women's involvement in political action. (Political action is broadly defined here to include indirect influence and informal or 'anti-system' activities.) Most important of all, feminism has helped us to see that politics and policies have always, directly or indirectly, affected women's life options through, for instance, prohibitions on birth control, confirmation of fathers' and husbands' authority, or the absence of effective protection or redress for women against rape.

Women's involvement in politics, the impact of politics on women, the politics of women's social position, and the politics of feminism have become widely debated issues and given rise to an extensive and rapidly growing but disparate literature. Much of this lies unambiguously inside the boundaries of political science, centring on women's political participation and, less frequently, on the politics of feminist issues. Some is historical or anthropological; some is less easily classified but sits loosely within other academic disciplines. Last but by no means least are the relevant writings issuing directly from the women's movement.

The primary objective of this book is to familiarise readers with the broad character and concerns of this literature, and to point to sources for further reading. But this is not simply an extended review. In the first place the 


\section{x Preface}

literature is too vast for such an enterprise to be comprehensively and fairly undertaken. In the second, it would not be particularly useful.

Instead, I have identified a number of themes that are, or should be, central upon which to organise the discussion. This means I have not attempted to reproduce each author's argument, although I hope I have not misrepresented them either, but have concentrated on analysis, whether empirical or theoretical, that helps to clarify and explain these themes.

Finally, in so far as I am offering an interpretation, I should declare my own political sympathies. This book is written from a feminist perspective. The various meanings of the term 'feminist' are discussed in the introduction; here it simply connotes, first, the belief that women share a common oppression, and, second, a commitment to its eradication. Although the approach of this book is academic rather than polemical, I hope that the kinds of questions it asks will be of relevance to debate and strategy within the feminist movement as well as to students of politics.

Many people have helped in the writing of this book, either directly through their information or advice or indirectly through their moral support. But specifically I should like to thank the following: Joanna Chambers, Judith Evans, David Ewens, Jane Hall, Jill Hills, Joni Lovenduski, my father (Charles Madge), Elizabeth Meehan, June Wyer and Robin Theobald. Thanks are especially due to Jill Hills and Elizabeth Meehan for letting me read the drafts of their respective manuscripts, to Chris Fowler for his typing, George Osborn for his assistance with the index, and Steven Kennedy for his patient and extremely helpful editing. As is customary to say, any faults of fact or interpretation remain my sole responsibility. 